\title{
Effect of Chicken Meatball Shelf Life With the Addition of Chitosan to Chemical Quality
}

\author{
Ikrima Rohimadilwa ${ }^{1}$, Ludfia Windyasmara ${ }^{2}$, Sri Sukaryani ${ }^{2}$ \\ ${ }^{1}$ Post Graduate Student Animal Science Faculty, Universitas Jendral Soedirman \\ ${ }^{2}$ Animal Husbandry Study Program, Faculty of Animal Husbandry, \\ Universitas Veteran Bangun Nusantara \\ Corresponding author: Ludfia Windyasmara \\ Email: windyasmaraludfia@gmail.com
}

\begin{abstract}
Chicken meatballs were one of the processed products that very popular and favored by the public because they taste good and are nutritious. One way to preserve chicken meatballs were using borax or formalin which were bad for health. Chitosan was a natural preservative that comes from shrimp and crab waste that can be used in the long term. This study aims to determine the effect of adding chitosan as a natural preservative for chicken meatballs stored at room temperature on the quality of chicken meatballs which include moisture content, $\mathrm{pH}$ value and protein content. This research method used a completely randomized design with long storage factors and the addition of chitosan. The data obtained were analyzed statistically using Analysis of Variance (ANOVA). Further test with the Duncan Multiple Range Test (DMRT) if there were a significant difference between treatments. The variables recorded and observed were moisture content, $\mathrm{pH}$ value and protein content of chicken meatballs at room temperature $\left(25^{\circ} \mathrm{C}\right)$. The water content of chicken meatballs up to $1.5 \%$ chitosan addition treatment showed the best consistency during the shelf life with an average value of $59.31 \%$. The $\mathrm{pH}$ value of chicken meatballs with the addition of $2.5 \%$ chitosan on the $2^{\text {nd }}$ and $4^{\text {th }}$ day gave a good effect with $\mathrm{pH}$ values of 5.56 and 5.78 , respectively. Protein content of chicken meatballs with the addition of chitosan $1.5 \%$ on the second day gave the effect of increasing the highest protein content up to $7.21 \%$.
\end{abstract}

Keywords: Chicken meatballs, Chitosan, Shelf life

\section{Introduction}

Meatballs are mashed meat, mixed with wheat flour, garlic, pepper and table salt. After that, it is formed in a round shape manually or with a tool with a size of between 3 $\mathrm{cm}-5 \mathrm{~cm}$, weighing 25 grams-30 grams per grain, which is cooked in hot water for ready-to-serve. Meatballs contain high protein, have a high water content and a neutral $\mathrm{pH}$ so they are prone to damage so that they have a maximum shelf life of one day at room temperature.

Chicken meat has high quality protein and contains amino acids that are needed by the human body. Apart from protein, chicken meat contains fat, carbohydrates, vitamins, especially the components of vitamin B complex, minerals and water. Each 
component varies depending on the species, age, and sex of the chicken concerned. Apart from its nutritional value, chicken meat also has several advantages such as: the price is relatively affordable, can be consumed by all levels of society and is sufficiently available in the market.

In this study, the authors tried to apply chitosan for food preservation, especially for meatballs. Meatballs are a food product with a relatively high water content, reaching $52 \%$. The shelf life of meatballs under normal storage conditions can only last 2 days. In order to get meatballs that have a longer shelf-life and quality that can be maintained, a preservative that are not harmful to human health is needed and can maintain the nutritional aspects contained therein.

\section{Materials and Methods}

\section{Research Material}

The material used for this research consists of main material and supporting material. The main ingredients are 2,000 grams of broiler chicken and chitosan powder. Supporting materials were tapioca flour, garlic, pepper, salt, and ice water.

The equipment used for processing meatballs were a meat grinder, a scale, a stove, a pan, a spice grinder, spoons, knives and various types of containers. The tools needed to test the moisture content are ovens, porcelain plates, scales, silica gel as a substitute for desiccators and various containers. The equipment used for the $\mathrm{pH}$ test were $\mathrm{pH}$ indicator, mortar and pestle. The equipment used for protein measurement were a kjeldahl flask, distillation device, erlenmeyer flask, test tube, beaker, measuring cup, fume hood, dropper pipette and burette.

\section{Experiment Design}

The experimental design in this study was to use a completely randomized design (CRD) factorial pattern with four treatments and three repetitions with each repetition consisting of three meatballs samples. Observations were made on day 0,2 and 4 . The form of treatment was the addition of chitosan to chicken meatballs with four treatments. In this study, there were two factors, namely:

1. Factor 1 (storage time) consists of :
a.T0 $=0$ days of storage
b.T1 $=2$ days of storage
c.T2 $=4$ days of storage

2. Factor 2 (the level of chitosan distribution) consists of:
a.P0 $=0 \%$ chitosan
b.P1 $=1.5 \%$ chitosan
c.P2 $=2 \%$ chitosan
d.P3 $=2.5 \%$ chitosan

\section{Variables Observed}

The variables observed in this study were water content, $\mathrm{pH}$ value and protein content. 


\section{Results And Discussion}

\section{Water Content}

The results of the water content statistical test showed that there was a significant difference in the percentage of water content in P0 (64.74\%) with P1 (59.31\%), P2 $(57.88 \%)$ and P3 (58.33\%). The statistical test of storage time at T0 (day 0), T1 (day 2) and T2 (day 4) showed no significant difference. The interaction between moisture content and storage time did not show a significant difference. With the addition of chitosan, it gave a fluctuating effect in water content which was not significant during the shelf life up to the $4^{\text {th }}$ day. This is in accordance with the statement of Henriette (2010) which states that chitosan can be used as a coating (film) on various foodstuffs, so that it can prevent oxygen from entering properly, so that chicken meatballs are not easily contaminated by the conditions around the meatballs.

Table 1. Average moisture content of chicken meatballs with the addition of Chitosan at $18^{\circ} \mathrm{C}$ of storage

\begin{tabular}{ccccc}
\hline \hline \multirow{2}{*}{ Storage Time } & \multicolumn{4}{c}{ Treatment $(\%)$} \\
\cline { 2 - 5 } & P0 & P1 & P2 & P3 \\
\hline T0 & $63.10^{\mathrm{a}}$ & $59.47^{\mathrm{be}}$ & $55.78^{\mathrm{cf}}$ & $59.20^{\mathrm{bdg}}$ \\
T1 & $63.63^{\mathrm{ab}}$ & $59.20^{\mathrm{ce}}$ & $57.79^{\mathrm{cf}}$ & $58.03^{\mathrm{cg}}$ \\
T2 & $67.50^{\mathrm{c}}$ & $59.26^{\mathrm{ae}}$ & $60.07^{\mathrm{af}}$ & $57.77^{\mathrm{ag}}$ \\
\hline Avarege & $64.74^{\mathrm{d}}$ & $59.31^{\mathrm{c}}$ & $57.88^{\mathrm{a}}$ & $58.33^{\mathrm{b}}$ \\
\hline
\end{tabular}

Numbers that follow the same letters in each row and column which show no significant difference in DMRT with a confidence level of $95 \%(\mathrm{p}=0.05)$

The addition of chitosan to chicken meatballs with a level of $2.5 \%$ showed the lowest water content of chicken meatballs during the study (57.77\%). These was accordance with the opinion of Winarno (1997) which states that the water content in food determines the freshness and durability of these foodstuffs, the high water content makes it easy for bacteria, fungi, and yeast to reproduce, so that changes will occur in food .

In this study, the addition of chitosan to chicken meatballs can maintain the water content of chicken meatballs from day 0 to day 4 , so that it can inhibit the growth of bacteria to reproduce and can extend the shelf life of chicken meatballs. These was in accordance with the statement of Linawati (2004) who argues that chitosan has a charged functional group that can bind to destructive microbes so that they can cause these microbes to die.

Based on the quality standard of meat balls according to the National Standardization Agency (SNI) in 1995, which states that the maximum water content in meatballs were $70 \%$. In this study, chicken meatballs stored at room temperature with different storage times had a moisture content of less than $70 \%$. Based on the National Standardization Agency for Indonesia (SNI) in 1995, the chicken meatball sample in this study fulfilled the meatball quality standard.

During the treatment period of giving chitosan, the water content of P0 $(63.10 \%)$ was greater than that of P1 (59.47\%), P2 (59.20\%) and P3 (55.78\%) during the shelf life 
from day 0 to day 4 . On day 2 (T1) the water content at P0 and P2 increased with values of $63.63 \%$ and $57.79 \%$, respectively. Treatment P2 and P3 decreased water content with a value of $59.20 \%$ and $58.03 \%$. Until the $4^{\text {th }}$ day, P3 treatment (Chitosan $2.5 \%$ ) had the lowest water content, namely $57.77 \%$. The highest percentage of water content was chicken meatballs with P0 treatment (Chitosan 0\%).

\section{pH value}

The statistical test results of the $\mathrm{pH}$ value in the treatment showed a very significant difference in the $\mathrm{pH}$ value of chicken meatballs with the addition of chitosan treatment at T0 (day 0), T1 (day 2) and T2 (day 4). Further test analysis with Duncan's test method showed that the average $\mathrm{pH}$ value in treatment $\mathrm{P0}$ (5.33) was very significantly different from P1 (5.63), P2 (5.56), P3 (5.78). Treatment P1 (5.63) was not significantly different from P2 (5.56) and P3 (5.78), which differed significantly. The average $\mathrm{pH}$ value of chicken meatballs showed a very significant difference at storage on day 0 (T0), day 2 (T1) and day 4 (T2). Advanced test analysis with Duncan's test method showed that the mean $\mathrm{pH}$ value at storage on day 0 (6.00) was very significantly different from the $\mathrm{pH}$ value of chicken meatballs on storage on day 2 (5.53) and day 4 (5.19). The interaction between the addition of chitosan and storage time (attachment 4) shows a very significant difference to the $\mathrm{pH}$ value of chicken meatballs.

Table 2. Average $\mathrm{pH}$ value of chicken meatballs with the addition of Chitosan at $18^{\circ} \mathrm{C}$ of storage

\begin{tabular}{ccccc}
\hline \hline \multirow{2}{*}{ Storage Time } & \multicolumn{4}{c}{ Treatment } \\
\cline { 2 - 5 } & P0 & P1 & P2 & P3 \\
\hline T0 & $6.00^{\mathrm{g}}$ & $6.00^{\mathrm{g}}$ & $6.00^{\mathrm{g}}$ & $6.00^{\mathrm{g}}$ \\
T1 & $5.33^{\mathrm{b}}$ & $5.89^{\mathrm{g}}$ & $5.33^{\mathrm{be}}$ & $5.56^{\mathrm{ab}}$ \\
T2 & $4.67^{\mathrm{c}}$ & $5.00^{\mathrm{b}}$ & $5.33^{\mathrm{de}}$ & $5.78^{\mathrm{abg}}$ \\
\hline Average & $5.33^{\mathrm{a}}$ & $5.63^{\mathrm{c}}$ & $5.56^{\mathrm{b}}$ & $5.78^{\mathrm{d}}$ \\
\hline
\end{tabular}

Numbers that follow the same letters in each row and column which show no significant difference in DMRT with a confidence level of $95 \%(\mathrm{p}=0.05)$

In this study, the mean $\mathrm{pH}$ value of each treatment ranged from 5.33-5.76 with the lowest value at $\mathrm{P} 0$ (5.33) and the highest at $\mathrm{P} 3$ (5.75). The $\mathrm{pH}$ value of meatballs without thickening material was more influenced by the $\mathrm{pH}$ of normal meat, which slightly increases due to processing factors. According to Suparno (1992), the $\mathrm{pH}$ of the meat will decreased according to the storage time, the longer it was stored, the lower the $\mathrm{pH}$ of the meat was until the final $\mathrm{pH}$ is reached in the range of 5.4 to 5.8. This means that the $\mathrm{pH}$ value of chicken meatballs in this study was in accordance with the opinion of Suparno (1992).

The results of the analysis of the average $\mathrm{pH}$ value in each treatment during the shelf life at room temperature from day 0, day 2 and day 4 showed a significant difference. From Tabel. 2 it can be concluded that there was a significant decreased in the $\mathrm{pH}$ value at $\mathrm{P} 0$ from day 0 , day 2 and day 4 .

According to Suparno (1992), the $\mathrm{pH}$ of broiler chicken meat will decrease according to the storage time, the longer the storage, the lower the $\mathrm{pH}$ of the meat. In this study, the addition of chitosan treatment gave an insignificant decrease in $\mathrm{pH}$ on the 
$\mathrm{P} 1, \mathrm{P} 2$ and $\mathrm{P} 3$ treatments compared to the P0 treatment during the storage period at room temperature on day 0 , day 2 , and day 4 .

Observation of $\mathrm{pH}$ was important because changes in $\mathrm{pH}$ affect the quality of the meatballs produced (Soeparno 1998 in Sudrajat 2007). In this study, each treatment on chicken meatballs showed a decrease in $\mathrm{pH}$ value on the $4^{\text {th }}$ day. Compared to treatment $\mathrm{P} 0$, treatments $\mathrm{P} 1, \mathrm{P} 2$ and $\mathrm{P} 3$ had a $\mathrm{pH}$ decreased that was not too far from the $\mathrm{pH}$ of chicken meatballs on day 0. These was in accordance with the opinion of Hafdani (2011) who argues that chitosan has antimicrobial properties, because it can inhibit pathogenic bacteria and decaying microorganisms, including fungi, gram-positive bacteria, gram-negative bacteria.

In food, chitosan can be used as an antimicrobial material to extend the storage time of food because chitosan contains lysosim enzymes and aminopolysacharida groups which can inhibit microbial growth (Wardaniati, 2009).

\section{Protein Content}

The results of statistical tests of protein content were significantly different in the addition of chitosan treatment. Protein content at P0 (5.54\%) was significantly different from P2 (6.41\%) but not significantly different from P1 $(5.78 \%)$ and P3 (5.96\%), while P2 $(6.41 \%)$ was significantly different from P0 (5.54\%) and P1 (5.78\%) but not significantly different from P3 $(5.96 \%)$. The mean protein content in chicken meatballs on day 0 , day 2 and day 4 showed a very significant difference. Duncan's advanced test showed a very real difference between T0 (5.30\%) and T1 $(6.28 \%)$ and T2 (6.18\%). Storage time treatment between T1 $(6.28 \%)$ and T2 $(6.18 \%)$ was not significantly different. The interaction between the addition of chitosan and storage time showed a very significant difference in the percentage of protein content in chicken meatballs.

Table 3. Average protein levels of chicken meatballs with the addition of Chitosan at $18^{\circ} \mathrm{C}$ of storage

\begin{tabular}{ccccc}
\hline \hline \multirow{2}{*}{ Storage Time } & \multicolumn{4}{c}{ Treatment } \\
\cline { 2 - 5 } & $\mathrm{P} 0$ & $\mathrm{P} 1$ & $\mathrm{P} 2$ & $\mathrm{P} 3$ \\
\hline T0 & $4.74^{\mathrm{ad}}$ & $4.37^{\mathrm{ac}}$ & $6.60^{\mathrm{bf}}$ & $5.52^{\mathrm{de}}$ \\
T1 & $6.29^{\mathrm{bc}}$ & $7.21^{\mathrm{b}}$ & $5.86^{\mathrm{bcf}}$ & $5.77^{\text {cdegf }}$ \\
T2 & $5.60^{\mathrm{cd}}$ & $5.76^{\mathrm{adh}}$ & $6.78^{\mathrm{fg}}$ & $6.59^{\mathrm{gh}}$ \\
\hline Average & $5.54^{\mathrm{a}}$ & $5.78^{\mathrm{b}}$ & $6.41^{\mathrm{d}}$ & $5.96^{\mathrm{c}}$ \\
\hline
\end{tabular}

Numbers that follow the same letters in each row and column which show no significant difference in DMRT with a confidence level of $95 \%(\mathrm{p}=0.05)$

In this study, the average protein content of chicken meatballs in each treatment was $5.54 \%-6.41 \%$. The protein content of meatballs according to the Indonesian National Standard (1995) was at least 9\%. This means that the chicken meatballs in this study have protein content below the SNI meatball standard. The low protein content in this study is due to the boiling process which can reduce the protein content of chicken meat in chicken meatballs. (Demodaran and Paraf, 1997) argue that processing using high temperatures will cause protein denaturation which will reduce the value of food protein. 
The addition of chitosan in this study can suppress the growth of pathogenic bacteria because chitosan has a positively charged polycation which can inhibit microbial growth (Wardaniati, 2009), and was able to bind with negatively charged compounds such as proteins, polysaccharides, nucleic acids, heavy metals and others. others (Murtini et al, 2008).

Table 3 shows that there was an increase in the percentage of protein in P2 (chitosan 2\%) and P3 (chitosan 2.5\%) on the fourth day of storage. The increase in protein was due to the addition of chitosan to chicken meatballs. Irianto et al. (2009) stated that the chitosan molecule has an $\mathrm{N}$ group capable of forming amino compounds which are components of protein formation.

Swastawati et al. (2008) have preserved pindang Terbang fish with $0.25 \%$ chitosan solution so that it can still be consumed until the second day. Likewise Wardaniati and Sugiyani (2009) use chitosan solution to preserve meatballs with a concentration of $1.5 \%$ so that they can be stored until the third day. Chitosan can be used as a preservative because of its properties, namely that it can inhibit the growth of destructive microorganisms and simultaneously coat the preserved products so that there was minimal interaction between the product and the environment. Chitosan works in two ways. First, chitosan can kill bacteria by binding pathogenic organisms with positively charged polikation. Organisms cannot grow or move. Second, chitosan will coat the outer skin of the preserved products, so that the taste from inside cannot come out and contaminants from outside cannot enter.

\section{Conclusion}

In this study, the chemical quality of the shelf life of chicken meatballs with the addition of chitosan stored at room temperature $\left(25^{\circ} \mathrm{C}\right)$ can be concluded that:

1. Water content of chicken meatballs up to the addition of $1.5 \%$ chitosan treatment showed the best consistency during the shelf life with an average value of $59.31 \%$.

2. The $\mathrm{pH}$ value of chicken meatballs with the addition of $2.5 \%$ chitosan on day 2 and day 4 gave a good effect with $\mathrm{pH}$ values of 5.56 and 5.78.

3. The protein content of chicken meatballs with the addition of chitosan $1.5 \%$ on the second day gave the effect of increasing the highest protein content up to $7.21 \%$.

\section{References}

Hafdani, F.N. and Sadeghinia. N., 2011. A Review on Application of Chitosan as a Natural Antimicrobial. World Academy of Science. Engineering and Technology, 50 .

Henriette, M.C. Azeredo, de Britto, D. and Assis., O.B.G., 2010. Chitosan Edible Films and Coating - Review, Embrapa Tropical Agroindustry, Fortaleza, CE, Brazil, ISBN 978-1-61728-831-9.

Irianto D, Elis P, Istiana, Sari E.C, 2009. Pengaruh penambahan chitosan yang diisolasi dari Limbah Cangkang Udang Windu (Penaeus monodon) terhadap Mutu Organoleptik, Mutu Kimia dan Daya Simpan. Jurusan Kimia Fakultas MIPAUniversitasNegeriSurabaya.http://davidirianto.blogspot.co.id/2009/02/peng 
aruh-penambahan-chitosan-yang.html. Diakses 16 Nopember 2016.

Linawati. 2004. Chitosan, Limbah Kulit Udang untuk Diabetes dan Hipertensi.http://kompas.com. Diakses 18 Juni 2016.

Murtini, J.T, Dwiyitno dan Yusma. 2008. Penurunan Kandungan Kolesterol pada Cumicumi dengan Chitosan Larut Asam dan Pengepresan. Prosiding Seminar Nasional Tahunan V Hasil Kelautan Tahun 2008. Jakarta.

Soeparno. 1992. Ilmu dan Teknologi Daging. Gajah Mada University Press. Yogyakarta Stadelman, W.J., V.M. Olson, G.A. Shmwell, S. Pasch. 1988. Egg and Poultry Meat Processing. Ellis Haewood Ltd.

Sudrajat, G. 2007. Sifat fisik dan organoleptik bakso daging sapi dan daging kerbau dengan penambahan karagenan dan khitosan. Fakultas Peternakan : Institut Pertanian Bogor

Wardaniati, R.A dan Sugiyani S. 2009. Pembuatan Chitosan dari Kulit Udang dan Aplikasinya untuk Pengawetan Bakso. Makalah Penelitian, (online), (http://eprints.undip.ac.id/1718/1/makalah_penelitian_fix.pdf, diakses 8 Oktober 2016).

Winarno . F.G. 1997. Kimia Pangan dan Gizi. PT Gramedia Pustakan Utama, Jakarta. 